Boise State University

ScholarWorks

$11-1-1992$

\title{
Imperial Power and Dictatorship: Britain and the Rise of Reza Shah, 1921-1926
}

Michael Zirinsky

Boise State University 


\section{Michael P. Zirinsky}

\section{IMPERIAL POWER AND DICTATORSHIP: \\ BRITAIN AND THE RISE OF \\ REZA SHAH, 1921-1926}

[Reza Khan] seemed to me a strong and fearless man who had his country's good at heart.

— Sir Edmund Ironside, recalling late 1920

Reza ... has never spoken for himself, nor ... [his] Government ... but only on behalf of his country....

- Sir Percy Loraine, January 1922

$\mathrm{He}$ is secretive, suspicious and ignorant; he appears wholly unable to grasp the realities of the situation or to realise the force of the hostility he has aroused.

- Harold Nicolson, September 1926

I fear we can do nothing to humanise this bloodthirsty lunatic.

- Sir Robert Vansittart, December 1933

Born in obscurity about 1878 and soon orphaned, Reza Pahlavi enlisted at fifteen in a Russian-officered Cossack brigade. Rising through the ranks, he provided force for a February 1921 coup d'état, seizing power for journalist Sayyid Zia alDin Tabatabai. Reza Khan provided strength in the new government and rose from army commander to minister of war (April 1921) to prime minister (1923) and, after failing to make a republic in 1924, to the throne in 1925. As shah he ruled with increasingly arbitrary power until Britain and Russia deposed him in 1941. He died in exile in $1944 .^{1}$

This paper examines British activity in Iran during Reza's rise to the throne and analyzes the longstanding belief that Britain made Reza shah of Iran. Within the context of Iranian and British history it tracks British involvement in the coup that first brought Reza to power and explores the policy of Sir Percy Loraine, British minister in Tehran, 1921-26. It shows that Britain did less than is believed by those who accept the myth, but more than London thought at the time: British aid to the coup was a key to its success, and aid to Reza helped him survive; Loraine's policy of good relations and nonintervention was part of the process by which Reza came to dominate Iran.

Michael P. Zirinsky teaches history at Boise State University, 1910 University Drive, Boise, Idaho 83725, U.S.A.

(C) 1992 Cambridge University Press 0020-7438/92\$5.00+.00 
THE IRANIAN CONTEXT FOR REZA'S RISE

Events during the years of Reza's rise, 1921-26, were crucial to Iran's survival as an independent state. Before the 1921 coup, the situation in Iran was chaotic. Central government authority had been weak throughout the Qajar period (17961925). After the 1896 assassination of Nasir al-Din Shah, Tehran seemed incapable of defending Iran against Russia and Britain or even of maintaining order. Its only modern forces were a Russian-officered Cossack brigade, established in 1879, and a Swedish-officered gendarmerie, established in 1911.

A long-standing civil-clerical rivalry added to the chaos. From the time the Safavids established Twelver Shicism as Iran's state religion in the 16th century, the public tended to identify Iran with Shicite Islam. Some ulema saw secular power as usurpation of the Hidden Imam's authority. During Qajar times the ulema put themselves forward as protectors against secular tyranny. During the Iranian revolutionary movement (the Tobacco Protest [1891-92] and the constitutional period [1905-11]), clergy also expressed hostility toward foreign influence, which seemed to be destroying Iran's independence and destabilizing the country, and mobilized mass support for national ideas. Nasir al-Din Shah withdrew the British tobacco monopoly and Muzaffar al-Din Shah accepted a constitution largely because the government could not resist clerically supported urban demonstrations. ${ }^{2}$

The presence of strong foreign powers contributed to instability. During the Constitutional Revolution, Iranian efforts to break Anglo--Russian control by establishing parliamentary government and pursuing a "third-power" policy failed, in part because proconstitutional forces in the new Majlis split between liberal democrats and more traditional moderates. Furthermore, central authority declined after democratic and tribal forces deposed Muhammad Ali Shah in 1909. Britain and Russia crushed Iran by the end of 1911 when they forced Morgan Shuster, an American hired by the Majlis as treasurer general, out of office and suppressed the assembly.

Attempts to oppose Anglo-Russian domination by tilting toward Germany and Turkey during World War I transformed Iran into a battlefield. Overrun during and immediately after the war by Russian, Ottoman, German, and British forces, about a quarter of the Iranian population died. After the collapse of Russia, Turkey, and Germany, British forces occupied much of Iran. England dominated Tehran's governments, subsidizing the shah, the cabinet, and the military. Consequently, Tabriz, Rasht, and Mashhad resisted Tehran's orders, and the tribes (about one-quarter of the population) ignored central authority. ${ }^{3}$

Iranian leaders responded to their country's situation in four ways, with a proBritish policy, a pro-Russian policy, a third-power policy, and with isolation.

\section{Pro-British Policy}

Some Iranians seemed to collaborate with British efforts to make Iran a protectorate, with mixed success. In 1919, at Lord Curzon's direction, British minister in Tehran Sir Percy Z. Cox negotiated a treaty with the government of Mirza Hassan 
Vosuq al-Dauleh that proposed to give Britain control of Iran's finances and armed forces. ${ }^{4}$ As soon as Vosuq, Foreign Minister Firuz Mirza, and Finance Minister Akbar Mirza Sarem al-Dauleh signed the Anglo-Persian Agreement on 9 August 1919 , they put into force some of its most important provisions without waiting for Majlis ratification.

In October, London designated Sidney Armitage-Smith as financial adviser to take charge of the Ministry of Finance. Part of his task was to induce Iran to repay millions of pounds Britain claimed Iran owed. Most of the money in question had been advanced to pro-British governments as subsidies or paid to maintain the British forces in the oil fields. Iran denied it owed the money, which it alleged Britain had spent on its own behalf. By the time Armitage-Smith arrived in Tehran in May 1920, Iranian opinion had so turned against the agreement that he received no cooperation. ${ }^{5}$

British officers were put in charge of Iranian àrmed forces. Major-General William E. R. Dickson, formerly inspector general of the East Persia Cordon, headed an Anglo-Iranian military commission charged with organizing a uniform army. Iranian opposition was deep; British-educated commission secretary, gendarmerie Colonel Fazlullah Khan, killed himself on 21 March 1920, rather than sign a report authorizing British command over the army. Many other Iranian officers, including Reza Khan, also felt strongly that they did not want to exchange Russian or Swedish masters for Britons. They wanted independence. ${ }^{6}$

The most effective opposition was passive. When Vosuq's decision not to convene a pliant Majlis became unacceptable to England, British minister Herman Norman (Cox's successor) had Ahmad Shah name Moshir al-Dauleh (Hassan Pirnia) prime minister in June 1920. When Moshir did not convene a Majlis, Norman had Muhammad Vali Khan (Sepahdar) put in charge in November. ${ }^{7}$

These politicians had mixed motives for working with Britain. To some extent they must have believed that survival dictated bending before overwhelming power. They may also have accepted Curzon's claim that the treaty guaranteed Iran's independence and territorial integrity. Certainly financial inducements played a role; Britain promised Iran a $£ 2$ million loan and paid the Iranian signers of the treaty a $£ 131,000$ bribe. $^{8}$ These men also were landowners whose properties were endangered by revolutionary events in Gilan which threatened to spread throughout Iran.

There were alternatives to collaboration. Other Iranian leaders responded to Iran's situation by trying to thwart British hegemony.

\section{Pro-Russian Policy}

Some Iranians-notably northern merchants whose trade with Russia Britain had embargoed - sought to restore equilibrium to Iran's policy by restoring good relations with Russia. The Soviets encouraged Iranian efforts to restore equilibrium by denouncing both the 1907 and 1915 partitions and also capitulations and concessions. This policy bore fruit in an Irano-Soviet treaty-negotiation for which was begun by the government of Moshir al-Dowleh-signed by Seyyid Zia's government on 26 February $1921 .^{9}$ 
Hope of restoring equilibrium was complicated by the Russian civil war. Under the command of General H. B. Champain after Dunsterville's retirement, the British North Persia Force (Norperforce) sought to support the Whites in the Caucasus. When Denikin was defeated, Norperforce retired to Enzali, Rasht, and Qazvin. Baku fell to the Bolsheviks in April 1920, and in early May Champain interned Denikin's Caspian Sea fleet at Enzali. Although the War Office, Treasury, and India Office had by this time concluded it was no longer feasible for the army to remain in such an exposed position, Foreign Secretary Curzon-still hoping for ratification of the 1919 agreement and fearing British withdrawal would doom it-blocked Champain's retreat. Alarmed by the threat of a continued White presence on the Caspian, the Bolsheviks attacked, overwhelming British forces at Enzali on 18 May 1920. Norperforce evacuated Rasht on 2 June, falling back to Qazvin. This British humiliation doomed Curzon's hopes; ${ }^{10}$ Soviet forces occupied Gilan, and Iran once again seemed partitioned between Russia and Britain.

Many Iranians therefore sought to act locally against what they saw as a puppet government in Tehran. Because they regarded restoration of equilibrium as a reasonable means of restoring independence, they opened themselves up to charges that they favored the Bolsheviks. Muslim nationalist Mirza Kuchik Khan led one such revolt from Gilan. In 1915, he launched the Jangali movement (popularly named after the jangal, the Caspian coast's thick forest) in favor of Iranian independence and in opposition to corruption. He accepted support from Ottoman panIslamic activists, who provided weapons used against Russia and Britain, as well as from Iranian democrats and socialists like Ehsanollah Khan. With the support of peasants and landlords he established an Islamic government calling for democratic, social, and national reforms. ${ }^{11}$

Entering Gilan in 1918 en route to Baku, Dunsterville forced his way through the Manjil pass against Jangali resistance. On 20 July the Jangalis burned the British consulate at Rasht, taking prisoners later exchanged for Democrat Suleiman Mirza Iskandari (jailed by Britain in 1916). To avoid becoming tied down, the British then worked out a modus vivendi with the Jangalis, which Champain broke in March 1919 at Vosuq's urging. When the 1919 agreement was announced the Jangalis gained wide, support. After the Soviets forced the British from Gilan, the Jangalis proclaimed a Soviet Socialist Republic at Rasht on 4 June 1920.12

This episode has been described as "the first Soviet experiment in Iran,"13 an effort to separate Gilan from Iran, perhaps even to annex it to the Soviet Union. While this may have been an object of some of Kuchik's more radical allies-such as Avetis Sultanzadeh ${ }^{14}$ and Seyyed Jafar Javad Zadeh Pishevari-Kuchik Khan himself and most of his supporters were motivated by Iranian patriotism and Shic ite Islamic values. This interpretation is supported by the Jangali exchange of British prisoners for Suleiman Iskandari as well as by Kuchik Khan's support from Democrats, ulema, and Ahmad Shah, who hoped Jangali success would reduce British influence.

Another revolt at this time was led by Sheikh Muhammad Khiabani, a clerical leader of the democratic movement in Azarbayjan. In the 1911 Majlis, he defended Morgan Shuster as a symbol of Iranian independence. During World War I he came into conflict with Ottoman officials in Azarbayjan; as a Shi ${ }^{\mathrm{C}}$ ite leader and 
patriot he opposed both Sunni domination of Azarbayjan and pan-Turanism. During the post-World War I struggle for Iranian independence, Khiabani was the leading democrat in Tabriz. Opposing the Vosuq government's acceptance of the Anglo-Persian agreement, in April 1920 he cut ties with Tehran and proclaimed Azarbayjan an autonomous azadistan (land of freedom). Tehran plotted against the democratic regime, inducing the Shahsavan tribe and the Shikkak Kurds under Ismail Agha Simko to harry Tabriz. On 13 September Cossacks seized Tabriz, shooting Khiabani two days later. ${ }^{15}$

Ultimately the Gilan Republic also failed. Extreme secular elements seized control of the government at the end of July 1920 and adopted policies to expropriate land and requisition food, transportation, and labor. These radical actions divided the supporters of the republic, mobilizing landlords, bazaaris, clerics, and peasants against it. Kuchik Khan opposed most radical policies as anti-Islamic, but he could neither prevent them nor deter sharp infighting among the radicals themselves. ${ }^{16}$

The Red Army's limited presence in Gilan acted as a shield for the Jangalis, inhibiting British and Iranian attacks. As a result of negotiations among the British, Soviet, and Tehran governments, however, the Soviets and British agreed to evacuate Iran. Norperforce withdrew in April 1921, as soon as the snows had melted sufficiently to permit withdrawal into Iraq, leaving its small arms, artillery, ammunition, and draft animals to the Iranian Cossacks. Soviet troops agreed to leave shortly thereafter. ${ }^{17}$ Internal dissension having weakened the Jangalis, Reza Khan's Cossacks defeated them in October; Kuchik Khan fled into the mountains and froze to death. An alternative to Reza's domination of Iran thus disappeared.

\section{Third-Power Policy}

Still other Iranians tried to rekindle a third-power policy by involving the United States in Iran as a counterweight to Britain, encouraged by American hostility to the exclusion of Iran from the Paris Peace Conference and to the Anglo-Persian agreement. Among the most prominent Iranians associated with this policy were British-educated Hosain Ala, a member of Iran's abortive peace-conference delegation and subsequently Iranian minister to the United States, and Ahmad Qavam al-Sultaneh, Vosuq's brother, who was governor of Khorasan in 1919-21 and twice prime minister between 1921 and 1923. Qavam sent Ala to Washington in 1921 to seek a loan, an oil concession for northern Iran, and technical assistance. Ala hired Morgan Shuster to act as an intermediary with New York banking and oil firms. ${ }^{18}$

From this initiative came the 1922-27 Millspaugh mission. With American government cooperation, Iran privately hired State Department petroleum adviser Arthur C. Millspaugh to be administrator general of Iranian finances, and charged him to streamline the collection and distribution of Iranian government revenue. Millspaugh's administration established new taxes, including excise taxes on tea and sugar and an income tax. Old taxes were rigorously raised, and unpaid taxes were collected. Budgets were made and balanced. Millspaugh's success in creating regular sources of revenue for the Iranian government, without resorting to taxfarming or foreign borrowing, essentially made Iran independent of foreign financial manipulation. ${ }^{19}$ 


\section{Isolation}

Another response to the postwar crisis, popularized many years later by Dr. Mossadegh as "negative equilibrium," was expressed at this time by Seyyid Hassan Modarres of Isfahan, the most important Islamic leader in the Majlis. During the Constitutional Revolution, Modarres helped to organize the moderates. During World War I, he was a member of the anti-British, anti-Russian Committee of National Defense. Later he supported the Jangali movement, hoping it would strengthen Iran against foreigners. As radicals came to dominate Gilan, Modarres feared Soviet penetration and control. He opposed the 1921 Irano-Soviet treaty as too favorable to Russia (especially its provision for Soviet invasion if Iran became a base for a hostile power). He opposed balancing British influence by making concessions to Russia, however. Like many patriotic Iranians afterwards, he sought to minimize both British and Russian involvement in Iran. ${ }^{20}$

These responses to the post-World War I crisis-pursuing balance in relations with great powers, seeking powerful friends, and opposing "foreign entanglements"-are enduring themes in Iran's search for a strong, national policy. They affected Reza's rise.

\section{BRITISH IMPERIAL CONTEXT}

Before turning to British involvement in the 1921 coup, a few words are necessary about Iran's place in British policy. Whitehall viewed Iran primarily as a buffer against Russian expansion toward India; after the discovery of oil, this too was important. For much of the 19th century Britain tried to maintain Iranian territorial integrity, but German emergence as a naval power caused Britain to seek a Russian alliance after 1905..$^{21}$

The resulting change in British policy toward Iran was not immediately clear. At the start of the Constitutional Revolution Britain encouraged constitutionalists, allowing them to protest inside the legation compound during the summer of 1906. ${ }^{22}$ In 1907, however, Britain and Russia divided Iran into spheres of influence; Tehran ostensibly lay in a neutral zone, but in effect they treated all Iran as their condominium. When World War I began, Iran became a theater of war on the eastern flank of the Ottoman Empire.

Anglo-Russian cooperation ended with the Bolshevik Revolution. After Soviet withdrawal from World War I, Britain continued alone to protect operations in Iraq, prevent the Central Powers from taking the Caucasus, stiffen resistance to the Bolsheviks, ease partition of Turkey, and safeguard interests in Iran. Curzon especially feared that Bolshevism might gain in India and consequently pushed for the 1919 Anglo-Persian Agreement.

Despite Curzon's concern, Iran was relatively unimportant to Britain. London's financial position was weak; Whitehall did not have enough money to defeat the Soviets, suppress unrest in Iraq, occupy Iran, and subsidize the Tehran government. The Treasury, War Office, India Office, and Colonial Office therefore urged withdrawal. To Foreign Office chagrin, politicians and the public seemed not to care about preserving Britain's position in Iran; they were more concerned with matters nearer home-including relations with France, Germany, and Ireland, and 
labor unrest in Britain. Over Curzon's objections, the cabinet decided to withdraw Norperforce in early spring 1921. The Foreign Office feared chaos would ensue, but a coup d'état during the night of 20-21 February secured Tehran. ${ }^{23}$

\section{BRITAIN AND THE COUP}

Tehran was taken by about 2,500 Cossacks led from Qazvin by Reza Khan who thus came to national power. The shah named Sayyid Zia prime minister. According to Donald Wilber, "The British command supplied boots ... cartridges ... uniforms, and sixty thousand tomans ... to cover the cost of moving ... soldiers from Qazvin to Tehran." ${ }^{24}$ Tehran rumor declared the coup a British enterprise, but Britain denied involvement.

Whose idea was the coup? Both Reza and Zia later claimed to have been its chief architect. At the time, British and American observers saw the coup as Zia's. ${ }^{25}$ Reza's role seemed minor. Norman's first reports indicated that Reza was only one of three military leaders, ${ }^{26}$ that he acted on behalf of $\mathrm{Zia}$, and that he had no political ambition. Afterward, Reza claimed to have been in charge all along, but this cannot be supported by contemporary evidence. Much later, Norperforce commander General Edmund Ironside claimed to have "engineered the coup d'état" on Reza's behalf. While there is no reason to doubt that he recognized Reza's ability and encouraged him, his published diary is consistent with an interpretation that Reza was only one of several plotters. ${ }^{27}$ But of all the conspirators, only Reza retained power.

British involvement with the coup included the following seven points.

1. Clearing the way. At the advice of Ironside and Norman, Ahmad Shah removed the Russian Cossack officers in late October 1920. Ironside saw the Russians as militarily incompetent, corrupt, and potential Bolsheviks, and he sought to establish the British command over Iranian armed forces envisaged by the 1919 agreement. Norman cabled London, "Expulsion of . . . Russian officers and virtual control by British officers of the only regular Military Force in Persia would make us practically independent of vagaries of Persian internal politics and in absence of external developments ensure gradual execution of [the 1919] agreement."28

2. Military assistance. Britons were assigned to the Cossacks and the gendarmerie to assist their training and prepare for a national army. Lieutenant-Colonel Henry Smyth was noteworthy as organizer of an abortive Azarbayjan gendarmerie force and as officer responsible for training the Cossacks at Qazvin during the winter of 1920-21. Ironside himself took an interest in the process and singled out Reza for promotion. The Qazvin Cossacks, armed and outfitted from British stores, were paid with British money. ${ }^{29}$

3. London proposes a new government. Irked by Sepahdar's weakness toward the Soviets and by cabinet pressure to evacuate Iran quickly, on 15 January Curzon told Norman to create a strong government, "either for purpose of conducting the affairs of the country from Tehran or, should evacuation of the capital become necessary, to provide a rallying point at Ispahan." 30 While there is no British evidence that the coup resulted from Curzon's wish, the matter depends in part on how well subordinates internalized Curzon's desire. British officials did aid the coup, independently.

4. Coordination. Britons acted as intermediaries between Sayyid Zia and the Cossacks. Contemporary accounts named legation Oriental Secretary Walter Alexander Smart as 
"privy to the whole proceeding." In addition to Lieutenant-Colonels Smyth and W. G. Grey (who both admitted involvement), legation staffer Victor Mallet and Captain C. J. Edmonds also may have been involved. ${ }^{31}$

5. Inviting the Cossacks to Tehran. Norman denied prior knowledge of the coup but played a major role in introducing Reza's Cossacks into Tehran. He admired Smyth's work with the Qazvin Cossacks, which he reported to Curzon on 24 January 1921. Meeting Smyth on 8 February, Norman suggested replacing the unruly Tehran Cossacks with a better disciplined Qazvin force. He hoped that Tehran Cossack commander Sardar-i-Humayun and his subordinate Sardar-i-Makhsus could be removed from office at the same time. Norman reported, "Colonel Smyth approved the proposal and expressed the intention of sending General Reza Khan, one of his best officers, to Tehran with these reliefs." 32

6. Gaining Iranian compliance. Norman also served as midwife at the birth of Seyyid Zia's government. On 20 February 1921, having heard that the Cossacks were nearing Tehran, Norman, "sent for General Westdahl, the Swedish chief of police, and impressed on him the importance, in case the Cossacks should enter the town, of seeing that his men confined themselves to their proper duty of maintaining public order and did not become involved in any fighting which might take place." The next day, Reza and Zia having seized Tehran "practically without striking a blow," Norman cabled London, "I saw the Shah this morning, and advised him to enter into relations with leaders of the movement and acquiesce in their demands, which is his only possible course. I was able to reassure him regarding his personal safety, and, though frightened, he did not talk of flight." ${ }^{33}$ Ahmad Shah then appointed Sayyid Zia prime minister and Reza military commander (sardar sepah).

7. Legation advocacy for Zia. Norman eagerly supported the new regime. Despite Zia's immediate revocation of Curzon's agreement, signing a Soviet treaty, and arresting many pro-British Iranians, Norman reported that Zia's government, "had been hailed with utmost satisfaction by [the] British community here as the most favourable to British interests which could possibly have arisen," and he appealed for support. The "general opinion here, which I share, is that Persia now has her last chance, and that if it is lost nothing can save the country from Bolshevism." Norman's enthusiasm rings hollow. Deeply troubled by rumor that he had planned the coup,${ }^{34}$ he may have been trying to put the best face on a situation over which he had little control.

Whitehall stalled. In reply to Norman's call for support of Zia, Iran desk officer George P. Churchill argued, "this would be all very well if there was any element of stability in the present regime at Tehran. In view of the uncertainty of the position it would ... be wiser to watch events for the present...." Curzon wired Norman on 28 February that, "Formal denunciation ... is not disguised by statement that no hostility to Great Britain is implied." Two days later Churchill noted, "The United States Minister's account of affairs at Tehran is not hopeful. These wholesale arrests, which Mr. Norman has not reported; the alleged hostility of the populace and the impression that the British are responsible for the coup d'état, lead to the belief that the present regime is not likely to be a success." ${ }^{35}$

Sayyid Zia could not retain power. Britain gave him no aid. Norperforce quickly withdrew into Iraq, leaving its small arms, artillery, ammunition, and draft animals to Reza's Cossacks. ${ }^{36}$ Zia crudely tried to obtain revenue by arresting many of the major landowners, but this weakened his support and provided fertile ground for alliances against him. In May, Reza-supported by Ahmad Shah, the landowning class, and Soviet minister Theodor Rothstein-forced Zia from office. Britain gave Zia refuge in Palestine, and Qavam al-Sultaneh came out of detention to become prime minister. ${ }^{37}$ 
Despite English help to the plotters, the coup did not aid Britain. London knew nothing about it, and Norman had little clue as to what Zia and Reza planned. What Britain chiefly got from the coup was the reputation of having been behind it, and that idea was proof to nationalists of England's perfidy. The coup chiefly benefited Reza Khan, newly placed at the center of the nation. His position subsequently strengthened when Norperforce left him its arms. Over the next years he used his new prominence to work for policies he favored and to augment his personal wealth and power.

\section{A PERIOD OF TRANSITION}

Although it is tempting to conclude that Reza Khan was already a dictator, ${ }^{38}$ his power was actually tenuous. During the next five years, in alliance with key Iranian political forces and with the support of Great Britain, he slowly increased his strength until he could crown himself shah.

During the Fourth Majlis (1921-23), Reza aligned himself with the Reformers' party-heirs of the moderates, whose landowner and ulema leaders included Qavam, Prince Firuz, and Modarres. Reza liberated Zia's prisoners, including Qavam and Firuz, and openly aligned himself with the ulema. In 1923 he welcomed ayatollahs Sheikh Muhammad Husayn al-Na ${ }^{\mathrm{C}}$ ini and Sayyid Abu al-Hasan al-Musavi al-Isfahani, who had been expelled from Najaf and Karbala by the British. Reza also coopted Prince Farmanfarma's nephew Dr. Muhammad Mossadegh and prevailed upon him to serve as finance minister in Qavam's 1921 cabinet and as governor of Azarbayjan for Moshir al-Dauleh's government in early 1922. ${ }^{39}$

The reformers shared with Reza aims of reducing foreign power and ending separatist movements. They supported elimination of foreign officers from the Cossacks and gendarmerie. When efforts to bring the gendarmerie under War Ministry control led to revolts in Mashhad (October 1921) by Colonel Taqi Khan Pasyan and in Tabriz (January-February 1922) by Major Lahuti Khan, who tried to mobilize local democrats against Tehran, the Majlis-including its democrats-supported Reza. Likewise, his army ended Kuchik Khan's Jangali movement in November 1921, terminated the independence of Simko's Shikkak Kurds during the summer and fall of 1922, and suppressed the Sanjabi Kurds in 1923.40

Reza Khan also cooperated with the reformers in support of a third-power policy. The Millspaugh mission helped to build the army by tapping Iranian wealth, and much of Millspaugh's success came at bayonet point. Much more than in Zia's time, Reza made good his 20 February 1921 statement to Walter Smart and Lieutenant-Colonels Haig and Huddleston at Mehrabad that "there was plenty of money in Persia, and [we] well know where to find it." Under Millspaugh's management, half of the government revenue was expended on the army. ${ }^{41}$

Reza's primary objective was to build the army. As early as May 1921, he indicated a desire for 100,000 men (almost twenty times the existing Cossack force). In the waning days of the Fourth Majlis he broke with Modarres over the conscription that would be necessary to recruit such a large army. ${ }^{42}$

After the Fourth Majlis ended (in October 1923) Reza had the shah name him prime minister, at the same time exiling Ahmad to Europe. Next, Reza used the army to rig elections for the Fifth Majlis (1924-25) in favor of secular reformers 
in the Tajadod (revival) and Socialist parties, heirs of the Democrats, who supported Reza's objective of a modern, centralized Iran.

Tajadod leaders included Ali Akbar Davar (educated in law at Geneva), Abdul Hussein Timourtash (Russian military education; governor of Gilan at the time of the suppression of the Jangali movement), Sayyid Muhammad Tadayun, and Muhammad Ali Foroughi (Zuka al-Mulk). These secular reformers aimed at erasing ethnic diversities and autonomist movements and, in 1921-26, sought to create a powerful central government that would introduce reform from above. Their program for national strength included the following policies: creating a well-disciplined national army and an honest professional bureaucracy, ending capitulations, settling the nomadic tribes, expanding Western-style state-supported schools (including girls' schools), opening careers to talent, encouraging Iranian capital development, separating religion and politics, and making Persian the national language. They were disillusioned with universal suffrage, since giving equal votes to peasants and the urban poor had enabled conservative landowners and the ulema to dominate the Fourth Majlis. They opposed provincial autonomy movements and favored strong central government. Tajadod and socialist objectives meshed well with Reza's own, and they were willing to work under military leadership..$^{43}$

Although Western viewers sometimes called this reform program socialist, it seems to have owed more to the liberal ideals of the 1789 French Revolution and of American Presbyterian educators, teaching in Iran since 1835, ${ }^{44}$ than of those of the Bolshevik Revolution. Tajadod support encouraged Reza to break with the Qajar past. His government imposed new taxes, planned a railway to be financed entirely by Iranian money, built new roads, established a national system of weights and measures, established a solar-based hijri calendar, imposed conscription, abơlished all aristocratic titles, and ordered the adoption of surnames. Tajadod leaders also supported Reza's continuing military campaigns to unite the country (as did other Majlis groups). During 1924 the army successfully campaigned among the Bakhtiaris and the Lurs. ${ }^{45}$

The Independents (munfaridin) - including Mustaufi al-Mamalek, Moshir alDauleh, Taqizadeh, Ala, and Mossadegh-also supported Reza within the Fifth Majlis. These constitutionalists hoped to tap Reza's energy for progress; Reza met them regularly, and they helped him toward supreme power. ${ }^{46}$

Reza miscalculated in March 1924 when he tried to establish a republic. Just before the Majlis under Tadayun's leadership was to vote, Turkey ended the caliphate, galvanizing Islamic opinion against a republic. While Modarres filibustered, other ulema-led demonstrations forced Reza to retreat. After a pitched battle between a crowd of 5,000 and two Pahlavi regiments in the Majlis garden on 22 March, Reza withdrew to the country. On 26 March he went to Qum to confer with ayatollahs Hairi, $\mathrm{Na}^{\mathrm{C}}$ ini, and Isfahani, after which they issued a joint statement that Islam prohibited a republic. Reza then resigned from the prime ministry in order to be restored by the Majlis. ${ }^{47}$

Rebuilding Reza's authority after this incident led to further violence. During the summer of 1924, the government encouraged an ulema-led anti-Bahai pogrom. In early July, the opposition poet and newspaper editor Mir Zadeh Eshqi was murdered by an unknown assailant rumored to be a government agent. On Friday, 18 
July, American consul Robert Imbrie was beaten to death by a crowd led by mullahs and largely composed of cossacks. Reza weathered the diplomatic storm created by Imbrie's murder and used it to establish martial law in Tehran and jail his opponents. ${ }^{48}$ Then in the fall, he departed for the south to complete the unification of the country by imposing his will on the previously autonomous Britishsupported Arab Sheikh Khazal of Mohammerah (Khorramshahr).

Once Khuzistan was subdued, Reza further consolidated his position. He cemented religious support, going to Najaf in January 1925 to confer with Ayatollah $\mathrm{Na}^{\mathrm{C}}$ ini before returning to Tehran. With the support of Modarres and Mossadegh, the Majlis then voted him the position of commander in chief of the armed forces, formerly a royal power. During the next months he moved to depose the Qajars, which the Majlis voted on 31 October 1925. Only Taqizadeh, Ala, Yahya Daulatabadi, and Mossadegh voted no. Mossadegh's argument that it was not "to achieve dictatorship that people bled their lives away in the Constitutional Revolution" was ignored. A Constituent Assembly was hastily chosen to change the constitution, and by its vote on 12 December Reza finally achieved total power. Only three Socialist deputies, including Suleiman Mirza Iskandari, abstained. No one opposed. ${ }^{49}$

SIR PERCY LORAINE'S MISSION

Reza Khan also had support from British minister Sir Percy Loraine. Contrary to previous policy, Loraine favored Reza's efforts to create a strong government, "a stable and self-dependent Persia, capable of maintaining herself unaided . . . a new Persia disciplined and homogeneous." 50

Before Loraine arrived in Tehran, Britain saw Iran as chaotic, a result especially of British bureaucratic disorganization. In addition to the legation, London received often conflicting reports on Iran from consuls, military attachés, the government of India, the Imperial Bank of Persia, the Indo-European Telegraph Department, and the Anglo-Persian Oil Company (APOC). In the cabinet, the Foreign Office had to defend its position against other departments whose arguments were strengthened by British public indifference to Iran. Treasury strictures minimized funds available for subsidies to the tribes and British forces. The Foreign Office denied funds to Qavam's government, which it regarded as hostile to British interests. Against Whitehall's advice, however, the Imperial Bank independently financed Cossack expeditions against autonomist movements. British confusion extended even to the key policy question of whether to support a strong central government (advocated by Curzon and the Imperial Bank) or to favor regional autonomist movements (preferred by the India Office and APOC). Affairs were not made easier by Curzon's angry reaction to Iranian repudiation of the agreement. The careers of Norman and Reginald Bridgeman, chargé d'affaires before Loraine's arrival, were both ruined by him..$^{51}$

Loraine accepted Curzon's invitation to be minister at Tehran knowing the danger to his career that failure would entail. Tehran was his first ministerial post. As minister, Loraine developed great influence with the Foreign Office. He cultivated Curzon's confidence, and the foreign secretary usually supported his recommendations. Loraine's conduct followed what Harold Nicolson would later describe as 
that of the ideal ambassador, "the chief channel of communication between his own government and that to which he is accredited," attempting to establish "that the word of command . . . be delivered by a single voice only, and not by a chorus of discordant voices." Loraine's reputation as a brilliant manager of British interests was well established by the time Curzon fell from office in December 1923 following Conservative defeat in the general election. Consequently, foreign secretaries Ramsay MacDonald (Labour) and Austin Chamberlain (Conservative) continued to give him a free hand. ${ }^{52}$

Loraine's career flourished in part due to his relationship with the Eastern Department head, his cousin Lancelot Oliphant. Before the foreign secretary saw Loraine's dispatches and telegrams, Oliphant almost invariably read and supported them. Oliphant was best man at Loraine's 1924 wedding, and they frequently exchanged long, personal letters. By modern standards, their correspondence suggests they were ethnocentric, arrogant, and acid tongued. For example, when Loraine first arrived in Iran he described some Iranian officials in the Gulf as "smelly" and "shifty brutes." He also called United States minister in Tehran Joseph S. Kornfeld a "backwoods Rabbi." Similarly, Oliphant called the newly appointed Italian minister to Iran, "as nearly white as one is likely to find among the ice creamers." 53 They seem to have assumed that conduct from those not of their social caste would be less than civilized.

Loraine often said Britain should not interfere in Iran's affairs. He described his policy about six months after he arrived in a letter to British resident A. P. Trevor at Bushire. After surveying the weakness of Britain's position and the depth of the opposition it faced, Loraine suggested that

We must go very warily, draw in our horns ... and rebuild our platform of action slowly and laboriously, seeing that the bases of our post-war policy have been cut away from under our feet. ... So I decline to interfere with Cabinet-making ... I decline to give a cent to the press, . . . and my tack is to let natural forces operate, while trying to make the Persians realize and shoulder their own responsibilities, in order that they may realize from their own experience, firstly their own ineptitude and secondly that it is positively in their own interests to be on good terms with us. ${ }^{54}$

Despite vowing noninterference, Loraine did involve Britain in Reza's rise in at least seven ways.

Advocate. Favorably impressed when they met, Loraine became Reza's advocate. "Reza Khan," he wrote on 31 January 1922,

is a powerfully built, well set up, big boned man, well above the average height, with a quiet voice and a direct manner of speech which is most unusual in a Persian. He gets straight to what he has to say, and does not waste time in exchanging the delicately phrased but perfectly futile compliments so dear to the Persian heart. ... . he has never spoken for himself, nor for the Government of which he is a member, but only on behalf of his country ... an ignorant and uneducated man; nevertheless he betrays no awkwardness of manner, nor self-consciousness, he has considerable natural dignity, and neither his speech nor his features reveal any absence of self-control. ${ }^{55}$ 
In short, Loraine believed Reza was a man with whom Britain could deal.

$\mathrm{He}$ also understood that Iranian opinion would reject Reza if Britain openly aided him. "It would, in my opinion, be most unwise to offer Reza Khan our support," he wrote, but, "if the conviction with which I have sought to imbue him, that England is the only real and disinterested friend of Persia, sinks into his mind, he will insensibly turn to us when difficulties arise for him, as they are bound to do, and we must then avoid any appearance of placing him under our protection." 56

Money. Loraine intervened with London to have the Imperial Bank of Persia advance money necessary to pay Reza's army. For example, on 6 February 1922, he cabled, " . . . we are just as much interested as the Persian Government in [Lahuti Khan's rebellion's] immediate suppression," and he urged the Bank immediately to grant Reza Khan a 500,000 -toman (approximately $\$ 500,000$ or $£ 100,000$ ) overdraft. Loraine believed that Reza's government was preferable to any which might replace it. He convinced London to smooth the way for the regular provision of financial support for Reza's army and government. ${ }^{57}$

The Millspaugh Mission. Loraine also shaped the work of the 1922-27 American financial mission. Iran engaged Americans in order to break British hegemony. Curzon endorsed the American mission after his own agreement failed, arguing, "The question by whom Persia is to be regenerated is of vastly less importance than that her regeneration should take place." Loraine encouraged the Americans to lay a financial foundation for a strong central government. "One day Persia may come to realize that her best chance of salvation lies in seeking the loyal aid ... of Great Britain," he wrote in May 1924, but "for the moment any chance of improvement centers around Reza Khan and the American advisers." 58 Loraine thus worked to prevent the Iranians playing the Americans against Britain.

Loraine assessed the mission in 1926. Before coming to Iran, "Dr. Millspaugh was not friendly toward Great Britain, and ... was mainly instrumental in drawing up the indictment against England ... seeking to establish a practical monopoly of the world's supplies of mineral oil." His idea of British aims, Loraine wrote, was "powerfully tinged by Mr. Morgan Shuster's notorious book, 'The Strangling of Persia." Although Millspaugh sought to free Persia from British encroachments, he never "desired and sought to undermine British practical influence in Persia"; he merely worked for "counterpoise to our influence." Loraine therefore left him on his own. By 1926 he believed Millspaugh was "convinced that British influence is never wantonly, unjustly or improperly used" and that "our silent sympathy and moral support ... [is] a definite asset to him in his task." "On the whole," he concluded, "such work as they have done has been well and truly laid. They have certainly improved the administrative organization of the Ministry of Finance; they have tightened up the collection of revenue; they have established a much more effective control over expenditure ... and have steadfastly discouraged the favouritism ... of the rich and powerful." 59 In short, Loraine concluded, the American mission had become an instrument of British policy, as Curzon intended, buttressing Reza's regime. 
Military Monopoly. Supporting consolidation, Loraine intervened with London to help Reza establish military monopoly. Loraine firmly supported Tehran's policy disarming the tribes and rebellious military units. He discouraged any support for dissidents by London or Iraq. He encouraged Whitehall to have Reza's army acquire war surplus equipment (especially mountain guns), rebutting India and War office arguments. Loraine also urged Reza be given credit to buy new British trucks, airplanes, and armored cars. He encouraged London to withdraw. Indian forces from the Gulf ports, leading to withdrawal from Bushire, occupied since $1778 .^{60}$

Prime Minister. Loraine took part in the events by which Reza made himself prime minister and exiled Ahmad Shah at the end of October 1923. In the spring Loraine urged Whitehall to allow him to assist Reza to become prime minister, arguing that Reza "... would be an inconvenient opponent: he might be a very useful friend." Loraine believed that Reza had gone far toward unifying Iran, that his success was in Britain's interest. The Iranian government, Loraine reported on 1 June 1923, was paralyzed and would continue so unless Reza took over. He asked for permission to suggest to the shah that he appoint Reza, "in such a way that refusal to entertain it would not commit us. ... " The Foreign Office demurred and on 5 June instructed Loraine to continue a policy of "complete disinterestedness."61

On 1 September 1923, Loraine again argued for intervention. Reporting Iranian instability and dissatisfaction with the American advisers, he argued, "Minister of War is alone unshaken and maintains strong position." There was a "growing conviction amongst Persians," he said, "of unpalatable necessity of coming to terms with Great Britain." Four days earlier the shah had demanded an interview with Loraine, who acted as "His Imperial Majesty's father confessor." The shah feared a coup by Reza, and Loraine reported that "His Imperial Majesty cared only for his [own] personal life and liberty." On 3 September Loraine reported that the shah feared Reza Khan "means to be the Persian Kemal" and, anxious about his own safety, intended to leave for Europe as soon as he could. Curzon feared that, "If the Shah were to desert his Kingdom, it would be the end of his dynasty," and suggested that "a douche of cold water on his idea of flight might invigorate his natural pusillanimity." 62

The crisis came to a head on 24 October 1923. The Iranian government had resigned, Loraine cabled, Reza would become prime minister, and the shah would leave the country. Reza knew the risks of becoming prime minister, Sir Percy concluded, but believed that no one else could govern. "He wants and needs British friendship." Two days later Loraine again reported to London that the shah "cannot resist demand of Minister of War to become Prime Minister ... [and] cannot remain here with him." Loraine eased the shah's departure. "His Majesty is in such a state of nervous anxiety about himself that he would be quite useless even if he remained," he argued, "I ... will facilitate [a] solution ... and am seeing [the] Minister of War about it. ..." On 28 October 1923, he cabled, "Shah behaved lamentably. Reza Khan sensibly. I think my intervention, though unusual, has had four good results, (1) prevented a deadlock, (2) preserved constitutional continuity, (3) earned gratitude of Shah, (4) placed new Prime Minister under an obligation." 63 
After the dust settled, the Foreign Office approved Loraine's action. Victor Mallet began by noting that Reza was supported by Iranian opinion.

Such terms as "public opinion," "patriotism," "honesty" and "idealism," when used in connection with Persia, are, of course, purely relative ... [but] the so-called Persian nationalist or "democratic" party reflects whatever public opinion is sufficiently educated to be articulate....

The fact that the terms "nationalist" and "democrat" .. . have become almost synonymous may seem odd to those who see in the nationalist ebullitions of a Mussolini the antithesis of democracy. But in Persia they are not wholly incompatible.

Mallet listed the points in dispute between Britain and Persia: the debt, the Iranian claim to Bahrain, order in Baluchistan, and Iranian recognition of King Faisal. If these could be resolved, Britain could withdraw its troops and support railway construction and a loan. He concluded,

Our essential interests in Persia demand a stable and strong central government, able to resist Russian penetration and the spread of Communist propaganda, to keep order on the trade routes, in the oil fields district and in the provinces on the Baluchi and Afghan frontiers, and to check the anti-British activities of the priesthood and the press. It is toward such conditions that Reza Khan appears to be aiming. If in the efforts to obtain his objective, he occasionally falls foul of some minor British interest, it may be that at times it will be worth our while to give way, if by so doing we enhance our position at vital points, the oilfields, the Gulf, the Indian and Iraq frontiers.

Oliphant approved this paper, noting that Reza "is patriotically minded and... may consolidate [Iran] to a degree not hitherto attained." 64

Sheikh Khazal. The most difficult part of Loraine's promotion of Reza was his role in the destruction of Sheikh Khazal of Arabistan. Britain sacrificed Khazal as a "minor British interest" while Reza established "a stable and strong central government." After many years of captivity, in 1936 Khazal "died in suspicious circumstances while [still] under house imprisonment." 65

Britain began to establish special relationships with tribal leaders in southwestern Iran when the Karun River was opened to navigation in 1888, increasing its presence in 1897 when the Lynch brothers built a "camel track" from Ahwaz to Isfahan. British presence again expanded with the development of the oil industry after the turn of the century. ${ }^{6}$

Khazal succeeded his murdered brother as sheikh in 1897, and Britain reinforced its special relationship with him on several occasions. Following assignment of southern customs control to Belgian administration and fearful of growing Russian interest, Britain gave Khazal written assurances of support in 1902. Sir Percy Cox repeated these assurances in 1907 and 1910. Cox and APOC representatives negotiated with Khazal, "rather than with ... Tehran for the oil company's first pipe line and the land on which to build the refinery at Abadan." Subsequently, Britain made Khazal a Knight Commander of the Indian Empire. Britain reiterated its guarantees of his autonomy after the outbreak of World War I, during which Khazal defended British interests. In 1919 Britain rewarded him with a river steamer "for his services during the war," and gave him "3,000 rifles and 
ammunition to enable him to protect the ... Oil Company and cover the withdrawal of British forces from Khuzistan." 67

Reza moved slowly against Khazal. His initial goal, to collect taxes, required moving troops into Khuzistan. At first Britain opposed this plan, fearing loss of the oil fields. Loraine tried to mediate between Khazal and Reza, and informed Khazal that British support depended on following British advice. Loraine advised Khazal not to resist Tehran and to pay his taxes; he also asked Reza to confirm Khazal's autonomy and not to move troops southward. Although Reza replied in a conciliatory manner, his troops moved south. ${ }^{6}$

Reza's growing power forced Britain to choose between continued support of local autonomy or a strong central government. Advocates of the southern policy included Cox, Arnold Wilson who was an informal adviser to Khazal as well as the APOC manager, George Churchill, and Walter Smart, who doubted that "Reza Khan could last twenty years, reconsolidate and reform Persia," and who argued against "throw[ing] away these southern trumps."69

The debate was already fully developed when Loraine cabled London on 5 May 1923, urging London to reexamine its Iranian policy. Loraine favored the central government against tribal autonomists. "To support Minister of War means the almost certain lapse of our local friendships of which the most important and difficult case is that of Sheikh of Mohammerah; but support might enable us to control Reza Khan to some extent and perhaps tie him down to definite assurances as regards Sheikh's position. Support would also strengthen bulwark against Russia." To oppose Reza, on the other hand, meant the "Gradual collapse of our position and influence unless we uphold them and our friends by force; Thwarting the one chance that has appeared for decades of stability of Persia under Persian control; A period of intense friction with Persian Government almost certainly leading to a rupture; [and] Playing into the hands of Russia."70

At first the Foreign Office opposed Loraine. Churchill argued for, "the policy already adopted," namely, "(a) support of the Bakhtiaris by financial means through the Anglo-Persian Oil Company ... and (b) support of the Sheikh of Mohammerah, even though such support may eventually lead to the dispatch of a gunboat to Mohammerah ... if Reza cannot be made to see the folly of his present course, it is possible for us to exert pressure upon him by withholding that financial assistance without which he will be utterly incapable of maintaining his army. . . "71

On 1 June 1923, Loraine reported that Reza and Prime Minister Mustaufi proposed to send two hundred men to Shushtar but were willing to guarantee not to interfere with the sheikh. London considered the request, cabling Loraine to, "insist as a sine qua non ... on previous written undertaking being given by Reza Khan ... and ... countersigned by Prime Minister."72

In October, Loraine sent London a memorandum prepared by military attaché Lieutenant-Colonel Sanders on the strength of the tribes and Reza Khan's plans to disarm them. Loraine concluded, "there is no reason why Serdar Sepah should not be able to carry out the scheme of disarming the tribes. ... I think the general result will be beneficial to British interests."73

The crisis began while Loraine was on leave. Reza provoked Khazal into open rebellion, and the Foreign Office sped Loraine back to Iran with instructions to 
"support Reza Khan and in the last resort throw over the Shaikh risking his total disappearance from Arabistan. ..." As Reza's troops approached, Loraine flew to Ahwaz and got Khazal to apologize for the rebellion. Although Loraine gave Khazal his word that he would urge Reza to withdraw and cabled Tehran to that effect, Reza did not retreat. Instead, Reza used the sheikh's Loraine-induced quiescence to tighten his grip on the entire province. On 24 November 1924, Reza informed Loraine that "the conditions ... for Khazal's pardon were unconditional surrender and his presence in Tehran." Four days later Khazal gave up, "ordered the disbandment of his forces ... and retired from Ahwaz to his palace at Mohammerah, where his yacht lay moored in the river." The next week, 6-8 December, Loraine mediated between Khazal and Reza at Ahwaz. Loraine tried to convince the sheikh he must capitulate. Khazal still believed he could count on British protection, and Loraine found it "amazingly difficult to get a new idea into his head ... even harder to dislodge an old one." In the end, however, he gained Khazal's agreement to a temporary Iranian occupation of Khuzistan. ${ }^{74}$

Reza's troops never left; in April 1925 they arrested Khazal and took him to Tehran, where he remained under house arrest until his death. Reza also seized Khazal's property. Despite legation advocacy, none was returned while Reza ruled. "The whole thing makes me very sad, because I have personal affection for the old man in spite of his failings," Loraine wrote. Well, it might have made him sad, but support for a strong Iranian government required Britain to renege on older pledges to local forces. Under Loraine's guidance, Britain chose to appease the emerging dictator Reza Khan. Loraine expressed pleasure at his achievement; Reza, he cabled, "is stronger and more popular than ever: he has understood for himself that our policy in the south is loyal and helpful and not disintegrating while Russian policy has been the reverse."75

The Crown. Finally, Loraine helped ease Reza's 1925 seizure of the crown. After his abortive 1924 republic, Reza hesitated. Perhaps he anticipated Dr. Mossadegh's later Majlis argument in opposition to the move; while as prime minister he was a fine servant of the country, as shah he would be responsible to no one. Perhaps, as Abrahamian suggests, he hesitated to lose support from the left. Perhaps, too, he paused because of the promise he had given Ironside in 1921 "not to take or allow to be taken any violent measures to depose the Shah." ${ }^{\prime \prime 6}$ More important than any promise was the matter of whether Britain would allow him to take the throne; Reza seems to have believed Britain could prevent it. The British diplomatic record is clear; Reza tried to discover how Britain would respond to such a coup. Loraine repeatedly reassured him that it was a purely Iranian affair, of complete indifference to London. Once Loraine convinced him that Britain would do nothing, Reza moved to establish his own dynasty.

By 1925 the Foreign Office had no use for the Qajars. Victor Mallet (George Churchill's successor at the Foreign Office) declared Ahmad Shah "a miserable creature entirely lacking in courage and quite untrustworthy." Oliphant agreed, writing on 10 July that "the Shah is a miserable and contemptible individual whose repeated statements that he is about to return to Persia no longer carry conviction with anyone." In October, Loraine cabled that Reza "must feel safe from 
interference in view of our repeated declarations of neutrality in internal affairs." Mallet commented, "Reza Khan's great hero is Nadir Shah: it would not be surprising if he were to model his career on that of Nadir. It would be madness for us to take any hand in this intricate and dangerous game now being played. ..." "77

Loraine could not escape being sounded. Iranian foreign minister Hassan Khan Moshar al-Mulk asked him on 20 October about the British government's attitude toward a change of dynasty. Loraine said that Britain would not take sides. This was not clear enough for Reza. The next day Moshar al-Mulk informed Loraine that Reza Khan "wants to get rid of [the] Kajars, but fears disapproval" of London; "he interprets silence as inconstancy." Loraine replied that, "I did not myself see what Reza Khan could hope for more than our loyal and friendly attitude of strict non-intervention." Whitehall approved, "Sir P. Loraine's [most judicious] language. ..." 78

This language also eased Reza's doubts. On 29 October Reza allowed Loraine "to understand that this time the issue with the dynasty will be pressed to a decision." Loraine's silence doomed the Qajars. Two days later the Majlis granted Reza headship of state until the meeting of a national constituent assembly. Despite outspoken opposition by Mossadegh, Taqizadeh, and Ala, Loraine cabled that the changes were well received. Qum and Najaf apparently accepted the change, and Modarres abstained from the vote. The Foreign Office noted that "the revolution has passed off calmly." 79

Loraine pressed London to recognize the new regime before any other power did so. On 2 November 1925, Britain granted "provisional recognition," which Reza received with the "liveliest satisfaction." Responding to this report, the Foreign Office noted that "the mutual understanding between Sir P. Loraine and Reza Khan is likely to be a valuable asset to us." 80

The Foreign Office guardedly expressed pleasure at the word that Reza intended to become shah. Mallet noted, "On the whole a monarchy seems the best regime for Persia, and there seems no good reason why Reza Khan should not found a new dynasty. Persian history presents many examples of such changes; indeed the Kajars themselves came in on a revolution, while Nadir Shah rose ... in a very similar way...." He added, "The Soviet will feel rather sore, if, having encouraged the elimination of the Kajars, they find another monarchy set up." Oliphant observed, "The world was a very different place when the Kajar dynasty was founded 150 years ago. While at the moment Reza Khan is clearly the only choice, it would be rash to cast a horoscope of his dynasty." 81

The Constituent Assembly met in Tehran on 6 December 1925, and on 12 December it voted to amend the constitution to grant the throne to Reza Khan, now styled His Imperial Majesty Reza Shah Pahlavi. Mohammed Reza Pahlavi was named heir to the throne. The coronation took place on 25 April 1926.

Vita Sackville-West wrote a vivid account of the coronation, which, read today, seems to foreshadow later events, to cast the horoscope which Oliphant feared to do. "In appearance Reza was an alarming man," she wrote, "six foot three in height, with a sullen manner, a huge nose, grizzled hair and a brutal jowl; he looked in fact what he was, a Cossack trooper," she observed, "nor had he any rival in the lax limp nation he had mastered." Participating with Lady Loraine in the 
selection of jewels to decorate the Gulistan Palace and the coronation robes, Sackville-West watched "linen bags vomit ... emeralds and pearls." Her view of the coronation was equally striking.

Expectancy and imminence brooded over the crowded hall, heightened by the silence; even whispers about the delay were now hushed; at last there came a stir; the doors were opened, and the figure of a little boy appeared. Quite alone, dressed in uniform, he marched down the length of the room, saluting, and took his place on the lowest step of the throne, His Imperial Highness, Shahpur Mohammed Reza, Crown Prince of Persia. Escorted by his Generals and his Ministers ... the Shah advanced towards the Peacock Throne. The European women curtsied to the ground; the men inclined themselves low on his passage; the mullahs shambled forward in a rapacious, proprietary wave; the little prince, frightened, possessed himself of a corner of his father's cloak. Only the silence seemed strange; one expected a blare of trumpets, a crashing of chords, and nothing came. Then from outside came a salvo of guns, making the windows rattle, proclaiming to the crowds in the streets that Reza Khan was King of Kings and Centre of the Universe. ${ }^{82}$

One should not make too much of this brilliant description, but it is hard not to see in it a foreshadowing of later problems.

Loraine, of course, expressed only satisfaction with the success of his policy and the new regime. Was he realistic or merely self-congratulatory? His successor Harold Nicolson believed that Loraine's picture was far too rosy. As early as 28 August 1926, he wrote critically of "Loraine's 'hero-worship' of Reza," and a month later he wrote a long dispatch urging a policy review. In particular, Nicolson criticized Reza Shah who he doubted had "the intellectual or moral calibre necessary for his high functions." Nicolson saw Reza to be "secretive, suspicious and ignorant ... wholly unable to grasp the realities of the situation or to realise the force of the hostility which he has aroused. His internal policy is apparently to discredit all possible rivals; his foreign policy is apparently to bribe his enemies and to abuse his friends." ${ }^{83}$ The Foreign Office angrily rejected this analysis, and, led by Oliphant, defended Loraine: Nicolson and Robert Clive, the new minister, were told to continue Loraine's policy of good relations and nonintervention.

By the end of 1927, however, it became clear to the British in Tehran that Reza Shah "is one thousand times worse than Ahmad Shah in his love of money and land, and in the short two years that he has been proclaimed Shah, he has amassed a huge, huge fortune." Eventually, the Foreign Office turned to share Nicolson's assessment of Reza. By 1932 they referred to him as "a dull savage of the sergeant-major type," and a year later a "bloodthirsty lunatic." For better or for worse, however, Loraine had bet Britain's interests on Reza and helped to make him shah. ${ }^{84}$

\section{CONCLUSIONS}

British involvement in the rise of Reza Shah grew out of complex interaction between two quite different histories. Politically aware Iranians loathed their country's weakness and occupation by foreigners after World War I and consequently supported Reza Khan's efforts to build a strong central government. Reza gained support from religious and secular nationalists for his military rule because of 
their disappointment with recent events. The ulema generally opposed foreign influence and also disliked the secular anticlericalism of the Tajadod and Socialist parties. They were won over by Reza's actions to end regional and tribal separatism, to reduce British and Russian financial and military influence, and by his seeming support of Islam. Their importance was clearly demonstrated in the 1924 republican episode, and their renewed support of Reza's stewardship helps to explain how Modarres, so effective in stopping a republic, failed to prevent his ascent to the throne. ${ }^{85}$

Likewise Reza gained the support of modernizing reformers, disillusioned with civilian weakness against British and Russian penetration and also with the results of universal manhood suffrage in the election of the Fourth Majlis. Understanding that under such a regime conservative landowners and the ulema would dominate elections, liberal reformers tied their fate to Reza's power in hope that his force could achieve their program. Reza did impose many of their reforms, against popular wishes. ${ }^{86}$

Any view of Reza's rise to supreme power in the years 1921-26 is inevitably colored by understanding of how he acted afterwards. How could a man so suspicious, intolerant of dissent, greedy, and brutal have had the support necessary to become shah? Obscuring the reality of this support, many people have argued that Britain made Reza shah. This is an exaggeration.

For over a century, Britain had regarded Iran as vital to its interests. Despite its weakness after World War I, England tried to extend its holdings. Meeting resistance from Arabs and Turks as well as Iranians, Whitehall adjusted its policy to accommodate nationalism. In Iraq, Britain recognized Faisal as king in 1921. In Egypt, Britain unilaterally proclaimed Egyptian independence in 1922, with reservations." Likewise at the Lausanne Conference (1922-23), Britain reluctantly accepted the Turkish nation-state. ${ }^{87}$ And in Iran after the failure of the 1919 Anglo-Persian agreement, Britain came to terms with nationalism by supporting Reza Pahlavi.

Britain encouraged Reza's rise in two stages. First, local agents gave tangible assistance to the February 1921 coup, for the most part without London's knowledge. Perceiving Soviet threat, British weakness, and Iranian disorganization and hostility, individuals acted to nudge Iranian politics in a seemingly helpful direction. While Ironside later claimed to have acted on Reza's behalf, contemporary evidence suggests that Norman, Smart, and Smyth favored others, notably Seyyid Zia. For various reasons-including London's unwillingness to support the Zia government, the firepower left to the Cossacks by Norperforce, and his own single-minded pursuit of national unity-Reza Khan became the chief beneficiary of the coup.

Second, Loraine aided Reza. When he went to Tehran he understood that money was short and the cabinet was divided but that Britain's interests remained fixed: to keep Russia at bay and protect the oil fields and other imperial positions in Iraq, the Gulf, and India. Early on Loraine decided Reza was the strongest player in Iran and that England did not have resources to impose a solution without him. His advocacy was reinforced when Mallet succeeded Churchill at the Foreign Office in 1923. Making a virtue of necessity, Loraine backed Reza as a man who could achieve order in Iran and thus further British interests. 
In retrospect, Loraine's support of Reza may have been naive and self-serving. Loraine disparaged cautionary voices, including Modarres, Ala, and Mossadegh. He also deprecated opposing views within the British establishment. Although Reza Shah did keep Russia out of Iran, he soon ended the capitulations, made demands on the APOC, and made claims on the British position at Bahrain and on the Iraq boundary. These Iranian initiatives should have been foreseen. Reza also weakened his own internal position by mistreating the Majlis and potential rivals, making more difficult long-term Iranian stability, which was perhaps Loraine's most important objective in appeasing his rise. This too Loraine might have foreseen.

Loraine aided Reza's rise in substantial, diplomatic ways. He removed obstacles, such as lack of money, opposition from Ahmad Shah and Sheikh Khazal, and Reza's own fear that Britain would intervene to stop his climb to the throne. Loraine took pleasure in having picked Reza as a potential winner and backing him early on, but that favorable diplomatic assessment was a self-fulfilling prophecy. British backing thus was part of the process by which Reza achieved sovereign power in Iran and became shah.

It was Reza Pahlavi's tragedy as well as Iran's that Dr. Mossadegh's warning about irresponsible power foreshadowed future problems. Reza Shah answered to no one, and his patience grew increasingly short. Power can corrupt; under Reza's absolute rule the Pahlavi state developed into a tyranny excoriated by liberal nationalists and Islamic activists alike. But that is another story.

\section{NOTES}

Author's note: Research for this paper has been supported by grants from the National Endowment for the Humanities, the Idaho State Board of Education, and Boise State University, for which I am truly grateful. Also, I would like to thank the staffs of the Public Record Office, Kew; the National Archives, Washington, D.C.; the Presbyterian Historical Society, Philadelphia; the British Library, and the National Army Museum, London, for their help. I presented an earlier version of this article at the 1989 Middle East Studies Association meeting in Toronto, and I want to thank critics of that paper, including Janet Afary, Lois Beck, John Foran, and Nikki Keddie, as well as my BSU colleagues Susan Medlin, Todd Shallat, and Driek Zirinsky.

${ }^{1}$ Reza took the name "Pahlavi" after coming to power; see Donald N. Wilber, Riza Shah Pahlavi: The Resurrection and Reconstruction of Iran (Hicksville, N.Y., 1975); L. P. Elwell-Sutton, "Reza Shah the Great: Founder of the Pahlavi Dynasty," in Iran Under the Pahlavis, ed. George Lenczowski (Stanford, 1978), 1-50. Also see Ervand Abrahamian, Iran Between Two Revolutions (Princeton, N.J., 1982); Hussein Makki, Tarikh-i bist saleh-i Iran (Twenty Years' History of Iran), 7 vols. (Tehran, 1983); Shahrough Akhavi, Religion and Politics in Contemporary Iran: Clergy-State Relations in the Pahlavi Period (Albany, 1980); M. Reza Ghods, Iran in the Twentieth Century; A Political History (Boulder, Colo., 1989); Nikki R. Keddie, Roots of Revolution: An Interpretive History of Modern Iran (New Haven, Conn., 1981); Peter Avery, Modern Iran (New York, 1965); Vincent Sheean, The New Persia (New York, 1927); Amin Banani, The Modernization of Iran, 1921-1941 (Stanford, Calif., 1961); Joseph M. Upton, The History of Modern Iran: An Interpretation (Cambridge, 1960), 36-80; and Michael P. Zirinsky, "Blood, Power, and Hypocrisy: The Murder of Robert Imbrie and American Relations with Pahlavi Iran, 1924," International Journal of Middle East Studies 18 (1986): 275-92.

${ }^{2}$ See Akhavi, 1-59; Vanessa Martin, Islam and Modernism; The Iranian Revolution of 1906 (London, 1989); Nikki R. Keddie, ed., Scholars, Saints, and Sufis; Muslim Religious Institutions since 1500 (Los Angeles, 1972), 211-55; Hamid Algar, Religion and State in Iran, 1785-1906 (Berkeley, Calif., 1969); Ahmad Kasravi, Tarikh-i mashruteh Iran (History of the Iranian Constitution) (Tehran, 1961); Malek al-Shua ${ }^{C}$ ra Bahar, Tarikh-i ahzab-i siyasi-i Iran (History of Political Parties in Iran) (Tehran, 
1944); Nikki R. Keddie, Religion and Rebellion in Iran: The Tobacco Protest of 1891-1892 (London, 1966); Michael M. J. Fischer, Iran from Religious Dispute to Revolution (Cambridge, 1980), 1-180; Nikki R. Keddie, ed., Religion and Politics in Iran: Shi ${ }^{i}$ ism from Quietism to Revolution (New Haven, Conn., 1983), 1-124; Keddie, Roots of Revolution, 1-78; Shaul Bakhash, Iran: Monarchy, Bureaucracy, and Reform under the Qajars, 1858-1896 (London, 1978); Ann K. S. Lambton, Qajar Persia (Austin, Tex., 1988); Janet Afary, "Peasant Rebellions of the Caspian Region during the Iranian Constitutional Revolution, 1906-1909," International Journal of Middle East Studies 23 (1991): 137-61.

${ }^{3}$ Houshang Sabahi, British Policy in Persia, 1918-1925 (London, 1990), 11-58.

${ }^{4}$ Documents on British Foreign Policy 1919-1939 [hereafter DBFP], ser. 1, vol. 13 (London, 1963), 429-749; Parliamentary Papers, "Persia No. 1 (1919)," Command 300; Papers Relating to the Foreign Relations of the United States [hereafter FRUS], 1919, 2:703-7; Harold Nicolson, Curzon; the Last Stage (London, 1934).

5J. M. Balfour, Recent Happenings in Persia (London, 1922); Sabahi, British Policy in Persia, 1132; Geoffrey Jones, Banking and Empire in Iran: The History of the British Bank of the Middle East (Cambridge, 1986), 1:191.

${ }^{6}$ Sabahi, British Policy in Persia, 45-46; Hassan Arfa, Under Five Shahs (London, 1964), 88-92; Wilber, Riza Shah.

${ }^{7}$ Sabahi, British Policy in Persia, 46-53.

${ }^{8}$ Curzon regarded Iranian demands for payment as "corrupt" and "odious," FO 371/7807; Cox obtained "a formal receipt" for the "backshish" from Sarem al-Dauleh, Oliphant, FO 371/6401; Jones, Banking and Empire in Iran, 191.

${ }^{9}$ Rouhollah K. Ramazani, The Foreign Policy of Iran; A Developing Nation in World Affairs, 1500 1941 (Charlottesville, Va., 1966), 187-90; Nasrollah Saifpour Fatemi, Diplomatic History of Persia, 1917-1923; Anglo-Russian Power Politics in Iran (New York, 1952), 255-307, $317 \mathrm{ff}$.

${ }^{10}$ Sabahi, British Policy in Persia, 61-73 passim; Curzon to Loraine, 30 May 1922; Loraine to Curzon, 2 August 1922, FO 1011/49. Loraine believed, "as early as our withdrawal from the Caucasus Vosugh made up his mind to throw over the agreement... General Champain's retirement when the Russians landed at Enzeli clinched it."

${ }^{11}$ Abrahamian, Iran Between Two Revolutions, 112.

${ }^{12}$ Ghods, Iran in the Twentieth Century, 52; Abrahamian, Iran Between Two Revolutions, 111.

${ }^{13}$ George Lenczowski, Russia and the West in Iran, 1918-1948; A Study in Big-Power Rivalry (Ithaca, N.Y., 1949), 48-60.

${ }^{14}$ Cosroe Chaqueri, "Sultanzade: The Forgotten Revolutionary Theoretician of Iran: A Biographical Sketch," Iranian Studies 17 (1984): 215-36.

${ }^{15}$ Ernest Bristow, consul at Tabriz, Annual Report for 1920, India Office Records, L/P\&S/11/196, P. 1803; Ali Azari, Giyami Sheikh Mohammade Khiabani dar Tabriz (The Revolt of Sheikh Muhammad Khiabani in Tabriz) (Tehran, 1983).

${ }^{16}$ Ghods, Iran in the Twentieth Century, 78-88.

${ }^{17}$ Ironside War Diary, 1920-21, National Army Museum, London (Lieutenant-Colonel Smyth acted for the Cossacks); Sabahi, British Policy in Persia, 108-38.

${ }^{18}$ FRUS, 1919, 2:698-719; British diplomatic resistance in the United States helped to thwart oil concessions granted to Standard (1921) and Sinclair (1924), as well as the loans tied to them; see FO 371, 34 (Persia) files, 1921-24; USNA, 891.51, 1921-24; Ghods, Iran in the Twentieth Century, 68-73.

${ }^{19}$ See FRUS 1927, 3:523-93; USNA, RG 59, 891.51 and 891.51A, includes copies of Millspaugh's quarterly reports; also see Arthur C. Millspaugh, The American Task in Persia (New York, 1925).

${ }^{20}$ Ghods, Iran in the Twentieth Century, 46-47, 91-98, 136, 158; Keddie, Roots of Revolution, 9192; honored today as a forerunner of the Islamic Republic, Modarres died under arrest in 1938.

${ }^{21}$ See Firuz Kazemzadeh, Russia and Britain in Persia, 1864-1914 (New Haven, Conn., 1968); Ramazani, Foreign Policy of Iran; Edward Ingram, The Beginning of the Great Game in Asia, 1828-1834 (Oxford, 1979); A. J. P. Taylor, Struggle for Mastery in Europe (London, 1954).

${ }^{22}$ See Martin, Islam and Modernism, 87-100; in 1902 Britain allied with Japan, whose victory over Russia in 1905 encouraged Iranian constitutionalists.

${ }^{23}$ Gordon Waterfield, Professional Diplomat: Sir Percy Loraine of Kirkharle Bt. 1880-1961 (London, 1973), 52 ff., 61 ff.; Harold Nicolson, Curzon: The Last Phase, 1919-1925 (London, 1934); Sabahi, British Policy in Persia, 1-138. 
${ }^{24}$ Norman, Tehran, 21 Feb., T. 121, FO 371/6401; 1 March 1921, D. 31, FO 371/6403; Denis Wright, The English Amongst the Persians During the Qajar Period 1787-1921 (London, 1977), 18084; Avery, Modern Iran, 224-28; Wilber, Riza Shah, 39-48.

${ }^{25}$ On 1 March 1921, Norman asserted that Sayyid Zia "was probably the originator of the whole movement," D. 31, FO 371/6403; Jordan to Robert Speer, 25 February 1921, PHS, RG-91-3-18.

${ }^{26}$ The others were St. Cyr-educated gendarmerie Major Masud Khan, minister of war in Zia's first cabinet, and Istanbul-educated Azeri gendarmerie Captain Qasem Khan (World War I veteran of the Ottoman army in Iraq), military governor of Tehran immediately following the coup, Norman, Tehran, 1 March 1921, D. 31, and 3 March 1921, D. 29, FO 371/6403. Masud and Qasem were attached to Lieutenant-Colonel Smyth for the organization of an Azarbayjan gendarmerie; Smyth brought them to Qazvin. Qasem was military attaché in Seyyid Zia's embassy to Baku in 1919-20, where he and Zia both associated with Smyth and other British officers, Wilber, Riza Shah, 40-41. Masud and Qasem fell from power with Zia in May 1921.

${ }^{27}$ In early 1922 Reza warned the press not to speculate about the coup, declaring, "I am the real plotter"; Ramazani, Foreign Policy of Iran, 176; Elwell-Sutton, "Reza Shah," 18. See Lord Ironside, ed., High Road to Command; The Diaries of Major-General Sir Edmund Ironside 1920-1922 (London, 1972), 149, 160-61; Richard Ullman, Anglo-Soviet Relations, 1917-1923, vol. 3, The Anglo-Soviet Accord (Princeton, N.J., 1972), 354-69, 383-89.

${ }^{28}$ Norman, 28 October 1920, T. 711, C9884/56/34; DBFP, ser. 1, 13:618 ff.; Ironside, High Road to Command, 135-46. Earlier, Reza quarreled with Cossack commander Starosselsky, "had himself [urged his removal] and when word came of the dismissal he was exuberant," Wilber, Riza Shah, 1215. Both Wilber and Avery (Modern Iran, 219) agree that Reza played a key role in the British-inspired 1918 removal of Colonel Clergé, Starosselsky's predecessor.

${ }^{29}$ Norman, Tehran, 3 March 1921, D. 29, FO 371/6403; Ironside, High Road to Command, 147-78; Ironside made Captain Reza Khan Cossack commander. Lieutenant-Colonel W. G. Grey gave an account of his role in the coup, "Recent Persian History," Journal of the Royal Central Asian Society, 13 (1926): 29 passim.

${ }^{30}$ Curzon, 15 January 1921, E667/2/34; DBFP, ser. 1, 13:698.

${ }^{31}$ Oliphant, memorandum of conversation with Dickson, 5 May 1921; Dickson wrote Curzon on 14 May 1921, that Smyth himself told him of his role, FO 371/6427. Smart had a history of independent action; Vanessa Martin, a student of E. G. Browne, noted that in 1906 he was "friendly to what [he] saw as a liberal constitutional cause," and she believed it likely that, privately, he encouraged the bastis at Golhak, Islam and Modernism, 92; also see Emile Lesueur, Les Anglais en Perse (Paris, 1922), 14853; Grey, "Recent Persian History"; Wright, English Amongst Persians, 180-84. In a letter to Norman, 27 February 1923, Oliphant criticized Mallet for entertaining Zia, since Mallet had been in the legation during the coup, FO 800, Oliphant papers, Pe/23/6. Proposed for Oriental secretary in Tehran, Edmonds was vetoed by Loraine, who noted, "Edmonds seems to have been mixed up in the Seyyid Zia coup d'état," FO 1011, 11, 14 February 1922.

${ }^{32}$ Norman, Tehran, 24 January T. 56, and 1 March 1921, D. 31, FO 371/6403.

${ }^{33}$ Norman, Tehran, 21 February T. 121, and 1 March 1921, D. 31, FO 371/6401, 6403.

${ }^{34}$ Norman, Tehran, 3 March 1921, T. 135, FO 371/6401; Norman expressed his dismay to Dr. Samuel Jordan, president of the American College of Tehran on 25 February, Jordan to Speer, 25 February 1921, PHS, RG-91-3-18.

${ }^{35}$ Curzon to Norman, 28 February 1921; Churchill, minute, 2 March 1921, reacting to an intercepted cable from United States minister Caldwell to Secretary of State Hughes; FO 371/6401.

${ }^{36}$ Ironside war diary, National Army Museum.

${ }^{37}$ Ghods, Iran in the Twentieth Century, 71.

${ }^{38}$ For example, Ellwell-Sutton, "Reza Shah," 18-20; Keddie, Roots of Revolution, 88.

${ }^{39}$ Abrahamian, Iran Between Two Revolutions, 131; FO 371/9046, 9047; Mohammad H. Faghfoory, "The Ulama-State Relations in Iran: 1921-1941," International Journal of Middle East Studies 19 (1987): 413-32; Akhavi, Religion and Politics, 27 ff.; Dr. Muhammad Musaddiq [Mossadegh], Musaddiq's Memoirs, ed., introd., and trans. Homa Katouzian (London, 1988), 5-10, $209-46$.

${ }^{40}$ Avery, Modern Iran, 254; Ghods, Iran in the Twentieth Century, 88; Ramazani, Foreign Policy of Iran, 180-81; IOR, L/P\&S/11/210, file no. 573; Abrahamian, Iran Between Two Revolutions, 120; Arfa, Under Five Shahs, 114-42. 
${ }^{41}$ Norman, Tehran, 1 March 1921, D. 31, FO 371/6403. Fourth Quarterly Report of the Administrator General of the Finances of Persia (Tehran, 24 September 1923), 84; preserved in USNA, RG 59, $891.51 / 328$.

${ }^{42}$ IOR, L/P\&S/11/197, P.2545, Foreign Office Correspondence with Henry W. R. Tarrant, Secretary and Manager, BSA Guns, Ltd.; Mahdi Farrukh, Khatirat-i siyasi-yi Farrukh (The Political Memoirs of Farrukh) (Tehran, 1969), 222-25, cited by Abrahamian, Iran Between Two Revolutions, 131; Akhavi, Religion and Politics, 37-38.

${ }^{43}$ Abrahamian, 121-26, 132-33; Bahar, Ahzab-i siyasi-i Iran, passim; Muhammad Ali Jazayery, "Kasravi, Iconoclastic Thinker of Twentieth-Century Iran," in On Islam and Shicism, ed., Ahmad Kasravi (Costa Mesa, Calif., 1990).

${ }^{44}$ See Michael P. Zirinsky, "American Presbyterian Education in Inter-War Iran" (paper presented at Middle East Studies Association, Los Angeles, November 1988); idem, "Harbingers of Change: Presbyterian Women in Iran, 1883-1949," American Presbyterians: Journal of Presbyterian History, forthcoming.

${ }^{45}$ Abrahamian, Iran Between Two Revolutions, 132-33.

${ }^{46}$ Katouzian, Musaddiq's Memoirs, 6-8; Mossadegh played a key role in Reza's election as commander in chief following suppression of Sheikh Khazal.

${ }^{47}$ Faghfoory, "Ulama-State Relations," 416-18; Akhavi, Religion and Politics, 28-31; USNA, RG59, 891.00, 1262, 1268; FO 371/10145, file no. 455; in particular note Oriental Secretary Havard's diary of events surrounding the failure of the republic, Tehran, 1 April 1924; Mossadegh was among those demanding Reza's return, Katouzian, Musaddiq's Memoirs, 7.

${ }^{48}$ Zirinsky, "Imbrie."

${ }^{49}$ Loraine, Tehran, T. 398, 12 December 1925, FO 371/10840; Katouzian, Musaddiq's Memoirs, 69; Ghods, Iran in the Twentieth Century, 93-100; Faghfoory, "Ulama-State Relations," 419 passim. Modarres spoke against deposing the Qajars but left the Majlis without voting. Neither he nor Mossadegh were elected to the Constituent Assembly.

${ }^{50}$ Nicolson, Tehran, 30 September 1926, D. 486, FO 371/11483.

${ }^{51}$ Norman, Tehran, 25 May 1921, and Churchill's response, 26 May 1921, FO 371/6404. The financial distress was general; see Martin Gilbert, Winston S. Churchill, vol. 14, 1916-22, The Stricken World (Boston, 1975), 531. Curzon revealed his frustration in a long letter to Loraine, 30 May 1922, ruing the "complete collapse of British prestige and influence ... and, as I judge, the universal execration of [our] friends," FO 1011; Waterfield, Professional Diplomat, 54-68.

${ }^{52}$ Waterfield, Professional Diplomat, 1-9, 51-52; Harold Nicolson, The Evolution of Diplomacy (New York, 1962), 75, 111.

${ }^{53}$ Oliphant to Loraine, 6 March 1923, FO 1011

${ }^{54}$ Loraine to Trevor, 6 July 1922, copy to Oliphant, FO 371/7807.

${ }^{55}$ Loraine, Tehran, 31 January 1922, FO 371/7804.

${ }^{56}$ Ibid.

${ }^{57}$ Loraine, Tehran, T. 83, 6 February 1922, IOR, L/P\&S/11; Foreign Office, Eastern Department, 34 (Persia) files, 1921-26; Jones, Banking and Empire in Iran; Sabahi, British Policy in Persia, 11-32, $108-40$.

${ }^{58}$ Curzon, 1 March 1922, FRUS, 1927, 3:524; Loraine, Tehran, 24 May 1923, FO 371/9024.

${ }^{59}$ Loraine, Tehran, 25 May 1926, FO 371/11498.

${ }^{60}$ Loraine, Tehran, 12 June 1923, FO 371/9024; Richard Cottam, Nationalism in Iran (Pittsburgh, Pa., 1979), 51-64, 102-17; Wright, English Amongst Persians, pp. 2-3, 62-74.

${ }^{61}$ Loraine, Tehran, 17 May, 21 May, 1 June 1923; Foreign Office, 5 June 1923, FO 371/9024.

${ }^{62}$ Loraine, Tehran, 1, 3, 8 September, Curzon, Foreign Office, 6 September 1923, FO 371/9024, 9025.

${ }^{63}$ Loraine, Tehran, 24 October, 26 October, 28 October 1923, FO 371/9025.

${ }^{64}$ Mallet, Oliphant, 14 November 1923, FO 371/9025.

${ }^{65}$ Abrahamian, Iran Between Two Revolutions, 150; Wright, English Amongst the Persians, 72.

${ }^{66}$ The Foreign Office regarded the "Lynch Road" as an important British interest; Wright, Persians Amongst the English, 150; Cottam, Nationalism in Iran, 111.

${ }^{67}$ British Documents on Foreign Affairs: Reports and Papers From the Confidential Print, pt. 1, ser. B, ed. David Gillard (Frederick, Md., 1985), vol. 18, Doc. 61, "British Assurances Given to the Sheikh of Mohammerah, 1899 and 1902-1910," 443-46; Wright, English Amongst Persians, 71-72; Wright, Persians Amongst the English, $190 \mathrm{ff}$. 
${ }^{68}$ Waterfield, Professional Diplomat, 68-70, an account of a 1922 Anglo-Iranian dispute over an Iranian army defeat in Khuzistan; Loraine took the part of Khazal and the oil company against Prime Minister Qavam, believing Qavam was trying to waylay Reza.

${ }^{69}$ Waterfield, Professional Diplomat, 78-79.

${ }^{70}$ Loraine, Tehran, 5 May 1923, FO 371/9024.

${ }^{71}$ Churchill, Foreign Office, 9 May 1923, FO 371/9024.

${ }^{72}$ Loraine, Tehran, 1 June 1923; Foreign Office reply, 5 June 1923, FO 371/9024.

${ }^{73}$ Loraine, Tehran, 6 October 1923, FO 371/9025.

${ }^{74}$ FO 371, 34 (Persia) files, 1924; FO 1011, Loraine papers; Waterfield, Professional Diplomat, 83-98. ${ }^{75}$ Ibid., 99-108; Loraine, Tehran, 5 January 1925, FO 371/10840.

${ }^{76}$ Abrahamian, Iran Between Two Revolutions, 135; Ironside, High Road to Command, 118, 161.

${ }^{77}$ Mallet, 3 March, Oliphant, 10 July, Loraine, Tehran, 13 October, Mallet, Foreign Office, 15 October 1925, FO 371/10840; Mossadegh believed "Ahmad Shah lost his throne because of his opposition to the Agreement. Honoured be a shah who would give up the throne for the good of his country," Katouzian, Musaddiq's Memoirs, 200.

${ }^{78}$ Loraine, Tehran, 20, 21 October, Mallet, Foreign Office, 22 October 1925, FO 371/10840.

${ }^{79}$ Loraine, Tehran, 29 October, 1 November, Mallet, Foreign Office, 2 November 1925, FO 371/ 10840; Akhavi, Religion and Politics, 30-32; Ghods, Iran in the Twentieth Century, 96-97; Avery, Modern Iran, 267.

${ }^{80}$ Loraine, Tehran, 3 November, Mallet, Foreign Office, 4 November 1925, FO 371/10840.

${ }^{81}$ Loraine, Tehran, 3 November, Mallet, Oliphant, Foreign Office, 4 November 1925, FO 371/10840.

${ }^{82}$ Vita Sackville-West, Passenger to Teheran (London, 1926), 142-49.

${ }^{83}$ Nicolson, Tehran, D. 486, 30 September 1926, FO 371/11484; this passage was omitted when, in 1968 , the British government published the document in DBFP, ser. IA, 2:812-20.

${ }^{84}$ FO 371/11484, file no. 92; Waterfield, Professional Diplomat, 134-38; James Lees-Milne, Harold Nicolson; a Biography, 1886-1929 (London, 1982), 243-320; minute, 7 December 1932, FO 371/ 16081; Sir Robert Vansittart, minute, 17 December 1933, FO 371/16942.

${ }^{85}$ Modarres, slapped during his filibuster against the republic on 15 March 1924, was shot on 30 October 1926; Tehran rumor held that the attack was commissioned by the chief of police on the direct order of the shah; Justice Minister Vosuq told British chargé Harold Nicolson that "all the evidence showed that the attempted murder was the work of the secret police"; Havard, Tehran, 1 April 1924, FO 371/10145; Nicolson, Tehran, 4 November 1926, D. 527, FO 371/111481; Modarres was imprisoned by Reza Shah in 1929 and killed in prison nine years later; Keddie, Roots of Revolution, 91-92.

${ }^{86}$ Sussan Siavoshi, Liberal Nationalism in Iran; The Failure of a Movement (Boulder, Colo., 1990), $51-52$.

${ }^{87}$ Harry N. Howard, The Partition of Turkey (Norman, Okla., 1931); Roderic H. Davison, "Turkish Diplomacy From Mudros to Lausanne," in The Diplomats 1919-1939, ed. Gordon A. Craig and Felix Gilbert (Princeton, 1953) 1:172-209; Aaron S. Klieman, Foundations of British Policy in the Arab World: The Cairo Conference of 1921 (Baltimore, 1970). 